\title{
Cross-reactive anti-PfCLAG9 antibodies in the sera of asymptomatic parasite carriers of Plasmodium vivax
}

\author{
Joana D'Arc Neves Costa ${ }^{1,3} /{ }^{+}$, Fernando Berton Zanchi², \\ Francisco Lurdevanhe da Silva Rodrigues ${ }^{1}$, Eduardo Rezende Honda', Tony Hiroschi Katsuragawa ${ }^{2}$, \\ Dhélio Batista Pereira ${ }^{1,3}$, Roger Lafontaine Mesquita Taborda1, Mauro Shugiro Tada ${ }^{1,2}$, \\ Ricardo de Godoi Mattos Ferreira ${ }^{2}$, Luiz Hildebrando Pereira-da-Silva ${ }^{1,2}$
}

${ }^{1}$ Centro de Pesquisa em Medicina Tropical, Porto Velho, RO, Brasil ${ }^{2}$ Instituto de Pesquisas em Patologias Tropicais-Fiocruz, Porto Velho, RO, Brasil ${ }^{3}$ Universidade Federal de Rondônia, Porto Velho, RO, Brasil

\begin{abstract}
The PfCLAG9 has been extensively studied because their immunogenicity. Thereby, the gene product is important for therapeutics interventions and a potential vaccine candidate. Antibodies against synthetic peptides corresponding to selected sequences of the Plasmodium falciparum antigen PfCLAG9 were found in sera of falciparum malaria patients from Rondônia, in the Brazilian Amazon. Much higher antibody titres were found in semi-immune and immune asymptomatic parasite carriers than in subjects suffering clinical infections, corroborating original findings in Papua Guinea. However, sera of Plasmodium vivax patients from the same Amazon area, in particular from asymptomatic vivax parasite carriers, reacted strongly with the same peptides. Bioinformatic analyses revealed regions of similarity between P. falciparum Pfclag9 and the P. vivax ortholog Pvclag7. Indirect fluorescent microscopy analysis showed that antibodies against PfCLAG9 peptides elicited in BALB/c mice react with human red blood cells (RBCS) infected with both $\mathrm{P}$. falciparum and $\mathrm{P}$. vivax parasites. The patterns of reactivity on the surface of the parasitised RBCs are very similar. The present observations support previous findings that PfCLAG9 may be a target of protective immune responses and raises the possibility that the cross reactive antibodies to PvCLAG7 in mixed infections play a role in regulate the fate of Plasmodium mixed infections.
\end{abstract}

Key words: malaria - immunity - Amazon - cross-reaction

The cytoadherence-linked asexual gene (clag) was initially identified in parasite lines with a deletion in chromosome 9 (Shirley et al. 1990) that lost the ability of binding to C32 melanoma cells bearing surface CD36 (Trenholme et al. 2000). Further sequencing of Plasmodium falciparum genome (Gardner et al. 2002), established that the chromosome 9 deletion (D10 deletion) affected a subtelomeric region containing 20 coding sequences. Additional experiments led to the identification of the gene encoding the CLAG protein containing nine exons (Holt et al. 1998, Gardiner et al. 2000). At the same time, a family of clag genes homologous to Pfclag9 was described (Holt et al. 2001). Clag family members were found on chromosome 2 (clag2), 3 (clag3.1 and clag3.2) and 8 (clag8). To date, three CLAG proteins were located in the rhoptries and they were associated to the high molecular weight protein complex of the RhopH family (Kaneko et al. 2001, Gardiner et al. 2004).

More recently, the functional and structural roles of other components of the clag gene family have been elucidated. The PfRhopH complex containing CLAG

Financial support: CNPq (Malaria Research), FINEP, MS/DECIT

+ Corresponding author: joanadarcneves@hotmail.com

Received 23 July 2012

Accepted 31 October 2012 proteins is composed of three subunits named RhopH1, RhopH2 and RhopH3 (Kaneko et al. 2005). In the mature schizont, the subunits are localised in the merozoites' rhoptries, whose contents are discharged at the moment of contact with the erythrocyte membrane, concomitantly with the formation of the moving junction and the parasitophorous vacuole (PV). The three protein known, components of the PfRhopH1 subunit (CLAG2, CLAG3.1 and CLAG9), are then discharged into the PV (Ling et al. 2004, Kaneko 2007, Iriko et al. 2008).

The rhoptry neck protein 2 is associated in erythrocyte invasion (Cao et al. 2009). It is expressed in the apical portion of the rhoptry in association with the RHopH1 complex that includes CLAG9. It is known that Plasmodium proteins can be exported to the host cell cytosol (Richard et al. 2010) via the translocon export complex of proteins that include the CLAG family. Thus merozoites can secrete directly products from the apical organelles into the PV and enter the PV membrane, or via the Plasmodium export element (de Koning-Ward et al. 2009, Mayer et al. 2009) they reach the erythrocyte plasma membrane. Therefore, the RhopH/CLAG complex discharged by the merozoites will participate in remodelling the infected red blood cells (RBCs).

Recent genetic experiments (Nguitragool et al. 2011) using clones obtained from the cross of HB3 and Dd2 $P$. falciparum strains showed that PfCLAG3 participates in the Plasmodial Surface Anion Channel formation. In addition, the traffic of PfCLAG3 after its injection into the cytosol and entry into the PV membrane (PVM) has 
been followed up to its final destination in the infected erythrocyte membrane. Goel et al. (2010) proposed that the exported PfCLAG9 also traffics to the erythrocyte membrane PfCSA variant antigen.

On the other hand, in recent studies, surprising conclusion concerning the functional role of CLAG9 has been reached (Nacer et al. 2011). In convincing detailed experiments using atomic force microscopy and knockout disruption of the $P f c l a g 9$ gene, it was shown that CLAG9 does not contribute to cytoadherence to CD36. Thus the non-adherent phenotype in the original D10 deletion of chromosome 9 (Shirley et al. 1990) must be dependent on another gene(s) encoded in the D10 deletion (Nacer et al. 2011). The authors conclude that CLAG9 function, like that of CLAG3 (Nguitragool et al. 2011), is associated with the metabolic requirements of the parasite.

Considering the important roles of the proteins encoded by the clag gene family in the life cycle of $P$. falcipar$u m$ at the asexual blood stages, including the erythrocyte invasion step, the participation of PfCLAG9 in the development of immunity to falciparum malaria was investigated in Papua New Guinea. A direct correlation with high antibodies titres against peptides representing linear epitopes of PfCLAG9 and immunity in semi-immune children and adults was found (Trenholme et al. 2005). In the present study we prepared synthetic peptides corresponding to different segments of PfCLAG9 and analysed their antigenicity in individuals from the Brazilian Amazon infected with falciparum or vivax parasites. Two groups were analysed: (i) individuals presenting clinical symptoms and (ii) asymptomatic parasite carriers.

\section{SUBJECTS, MATERIALS AND METHODS}

Study site and population - The study was performed with patients from suburban and rural riverside areas of the Rio Madeira in Porto Velho, capital of the state of Rondônia (RO), an area with a high incidence of malaria located in the Brazilian Amazon.

The population presents a profile of several previous episodes of malaria, as described (Tada et al. 2007). This characteristic of the population due to a high density of the Anopheles darlingi vector (Gil et al. 2003, 2007). Annual parasite index levels found for residents of these localities were 200-800, in association with the development of natural immunity among long time residents and a prevalence of asymptomatic malaria parasite carriers in the adult population varying from $15-30 \%$ for Plasmodium vivax and $5-10 \%$ for P. falciparum (Katsuragawa et al. 2009, 2010). Control measures developed in recent years, based on new formulations of drugs against $P$. falciparum malaria, have reduced the risk of $P$. falciparum infections in the studied areas to less than $10 \%$ (Epidemiologic Surveillance of Information System/ Brazilian Health Ministry) (portalweb04.saude.gov.br/ sivep_malaria/default.asp). The county of Porto Velho still accounts for $10 \%$ of the total $P$. vivax and $P$. falciparum malaria cases in Brazil.

Diagnostic, sera collection and processing - Sample collection of parasites, as well as blood sample collection and processing, have been previously described (Tada et al. 2007). Malaria infection diagnostic proce- dures were performed by microscopy examination and nested polymerase chain reaction (PCR) methods. The protocol used was based in Snounou (1996) and used genus-specific (rPLUS5 and rPLUS6) and species-specific (rFAL1,rFAL2, rMAL1, rMAL2, rVIV1 and rVIV2) primers. Briefly, the $20 \mu \mathrm{L}$ of reaction volume per tube consisted of $250 \mathrm{~nm}$ of each primer, $125 \mu \mathrm{M}$ dNTPs, 2 $\mathrm{mM} \mathrm{MgCl} 2,50 \mathrm{mM} \mathrm{KCL}, 10 \mathrm{mM}$ Tris $\mathrm{pH}$ 8.3, 0.4U Taq polymerase (Invitrogen) and $1 \mu \mathrm{L}$ of genomic DNA. In the first PCR, the samples were subjected to initial denaturation at $95^{\circ} \mathrm{C}$ for $5 \mathrm{~min}$, a step at $58^{\circ} \mathrm{C}$ for $2 \mathrm{~min}$, a step at $72^{\circ} \mathrm{C}$ for $2 \mathrm{~min}$ that was followed by 30 cycles at $94^{\circ} \mathrm{C}$ for $1 \mathrm{~min}, 50^{\circ} \mathrm{C}$ for $2 \mathrm{~min}, 72^{\circ} \mathrm{C}$ for $2 \mathrm{~min}$ and a final step at $72^{\circ} \mathrm{C}$ for $5 \mathrm{~min}$ in Gene $\mathrm{Amp}^{\circledR}$ PCR System 9700.

The second reaction was performed with 35 amplification cycles. All PCR assays included positive control (P. vivax, P. falciparum) and negative controls (ultrapure water). The fragments were separated by electrophoresis on a $1.5 \%$ agarose gel in tri-borate-ethylenediamine tetraacetic acid buffer and were visualised with ethidium bromide (Invitrogen) or Blue Green (LCG Biotechnologies, Brazil) under ultraviolet light. Asymptomatic malaria parasite carriers were defined by PCR detection of parasites in the absence of clinical symptoms and signs of malaria in the 30 days of surveillance following the positive examination.

Human serum samples - Serum samples were obtained from two groups of malaria patients: (i) Those who actively sought malaria treatment and who showed symptoms of acute malaria and positive blood smears for P. falciparum or P. vivax. These sera were collected between 2006-2008 in the Malaria Post of the Centre for Research in Tropical Medicine (CEPEM). (ii) Another group of sera was obtained from asymptomatic individuals patients living in the malaria endemic localities in the suburban and rural localities of Vila Candelária, Cachoeira do Teotônio, Santo Antônio and Vila Amazonas of Porto Velho (Tada et al. 2012). Asymptomatic sera were thus classified as those from individuals in the same localities, with positive PCR for $P$. vivax and/or $P$. falciparum and without recorded clinical symptoms for at least 30 days period after the positive PCR diagnosis.

CLAG9 peptides - The selection of synthetic peptides representing possible epitopes of CLAG9 (GenBank 167963009) (ncbi.nlm.nih.gov/genbank) was based the following programs: Flexibility Prediction (Karplus \& Schulz. 1985), Hydrophilicity Prediction (Parker et al. 1986), Antigenic Propensity (Kolaskar \& Tongaonkar 1990), Bepipred Linear Epitope Prediction (Larsen et al. 2006) and Surface Accessibility Prediction (Emini et al. 1985). Calculations in each method were made using the software Antibody Epitope Prediction available from the Immune Epitope Database (immuneepitope.org/tools/ bcell/iedb_input). The three selected peptides derived from PfCLAG9 were named A, B and C (Fig. 1) and were synthesised at GenScript (Piscataway, NJ, USA). The comparison between PfCLAG9 and PvCLAG7 (GenBank 156081674) and PvCLAG8 (GenBank 156096581) proteins was done using the CLUSTALW software (Thompson et al. 1994). 
Antibody reactivity to synthetic peptides in sera of malaria patients - All serum samples from malaria patients as well as negative controls were tested in duplicate by the enzyme-linked-immunosorbent-assay (ELISA) as described by Braga et al. (2002). This test was performed thrice. The cut-off value was defined as the mean plus two standard deviations of the absorbance values obtained with 64 negative control sera from malarianaïve blood donors living in Porto Velho and São Paulo. The cut-off absorbance values used to define positive results were $0.216,0.226$ and 0.236 for peptides A, B and $\mathrm{C}$, respectively. The results were expressed as reactivity index (RI) defined by optical density $(\mathrm{OD})_{450 \mathrm{~mm}}$ values of tested samples divided by the value of the cut-off. Values of RI > 1.0 were considered positive.

Immunisation of $B A L B / C$ mice with synthetic PfCLAG9 peptides - Female BALB/c mice (4-6 weeks old) were immunised intramuscularly with three doses of 50 $\mu \mathrm{g}$ of peptide for each synthetic peptides A, B and C (5 mice per group). The first dose of peptide was emulsified in Freud's complete adjuvant (Sigma) and the two subsequent peptide boosters 20 and 40 days later were emulsified in Freud's incomplete adjuvant (Sigma). Sera were collected prior to the first immunisation and 20 days after administering the last booster dose. The sera of each group of mice were pooled and stored at minus $20^{\circ} \mathrm{C}$ until use.

Parasitised RBCS (PRBCS) preparation and immunofluorescence antibody test (IFAT) - P. falciparum 3D7 (Walliker et al. 1987) PRBC were obtained from parasite cultures as described by Trager and Jensen (1976). Parasite cultures were synchronised by sorbitol lysis (Lambros \& Vanderberg 1979) and trophozoites and schizonts obtained as in Lelievre et al. (2005). For $P$. vivax infected $\mathrm{RBCs}$ isolation, peripheral blood samples from donor's patients with $P$. vivax malaria were collected into $20 \mathrm{~mL}$ of heparinised containing vacuntainer tubes. PRBCs in stage of trophozoites and schizonts were concentrated using a discontinuous Percoll gradient (GE Healthcare) (Andrysiak et al. 1986). Thin smears were prepared and placed on multisport slides at room temperature and stored at $-80^{\circ} \mathrm{C}$. Slides were fixed with formaldehyde for $2 \mathrm{~min}$, washed twice with phosphate buffered saline (PBS) according to a previously established protocol (Nacer et al. 2011). Slides were incubated in humid chamber for $1 \mathrm{~h}$ at $37^{\circ} \mathrm{C}$ with primary antibody (mouse anti-peptides A, B, C and negative control - polyclonal antibodies) diluted to $1: 40$ in blocking buffer $(0,5 \%$ gelatin, $1,5 \%$ bovine serum albumin, $0,02 \%$ Tween 20 in PBS). Sequentially, slides were washed three times with PBS and incubated with goat anti-mouse IgG Alexa Fluor 488 (1:600) (Life Technologies) $45 \mathrm{~min}$. Nuclei was stained with $0.2 \mathrm{mg} / \mathrm{mL}$ 4'6-diamindino-2-phenylidole (Sigma) for $5 \mathrm{~min}$ and finally mounted and examined using fluorescent microscope (Nikon eclipse 80i).

Statistical analysis - Statistical analysis was evaluated using GraphPad Prism 5 for Windows ${ }^{\circledR}$. All comparisons were between groups defined as asymptomatic and symptomatic malaria parasite carriers. For quantitative data, the non-parametric data, the Mann-Whitney $U$ test was applied (RI comparisons considering only positive values). For qualitative data (positive and negative sera) Fisher's exact test applied. Confidence intervals of $95 \%$ were also calculated.

Ethical statements - The research protocols for human subjects were approved by the Ethical Research Committee (CEP) of the CEPEM in accordance with ethical principles of conduct. Blood samples of individuals in the study population were collected after informed consent and written agreement of each individual of the population sample (CEP-CEPEM decision 25/2004, Candelária; 49/2006, Porto Velho CEPEM; 70/2008, Sector Santo Antônio - Teotônio, Cachoeira do Teotônio - Santo Antônio). All procedures for mice immunisation and preparation of anti-PfCLAG9 antigens sera were evaluated and approved by the Ethical Committee on Animal Use of the Research Institute of Tropical Pathology-Oswaldo Cruz Foundation (2009/2).

\section{RESULTS}

Antibodies against PfCLAG9 A, B and C peptides present in malaria patients - The first ELISA test were performed in sera of falciparum malaria patients $(\mathrm{n}=$ 115), independent of or not with clinical symptoms at the time of blood sampling. As negative controls $(n=64)$ and sera from vivax malaria patients $(\mathrm{n}=139)$. Surprisingly, positive values were obtained in the sera of vivax patients, with stronger signals in asymptomatic parasite carriers (Table).

The results presented in Table confirm previous observations with P. falciparum patients in Papua New Guinea (Trenholme et al. 2005), showing higher ELISA RI values for peptides A, B and C in asymptomatic carriers than in patients with clinical symptoms. However,



Fig. 1: localization of the three synthetic peptide (Pep) in PfCLAG9 protein. Peptide A reproduces the 32 amino acid sequence from the residue 728-760, peptide B reproduces the 43 amino acid (a) sequence from residue $901-944$ and peptide $\mathrm{C}$ reproduces the 56 amino acid sequence from the residue 1284-1340. 
a high proportion of sera from $P$. vivax patients also recognised the A, B and C peptides of PfCLAG9 and the intensity of the responses correlated with clinical immunity to vivax infections.

Nevertheless, positive values were found in $90-100 \%$ of all $P$. falciparum patient samples, while the frequency was $40-60 \%$ of symptomatic $P$. vivax patients and 80 $90 \%$ of asymptomatic subjects. When considering only the reactive sera among clinical patients samples, the average RI value observed was two-three fold higher in P. falciparum than in P. vivax patients. However, for asymptomatic carriers of both parasite species the observed RI values were equivalent (Table).

Antibodies against merozoite surface protein (MSP) $1-_{19}$ antigens of $P$. falciparum or P. vivax origin in sera of symptomatic and asymptomatic vivax malaria patients Our results suggest that some symptomatic or asymptomatic $P$. vivax patients had been previously exposed to $P$. falciparum infections. To study this possibility we tested all sera against recombinant MSP1- ${ }_{19}$ antigens of $P$. vivax and of $P$. falciparum origin (PvMSP1- ${ }_{19}$ and Pf MSP1- ${ }_{19}$ ).

Fig. 2 and Table compare ELISA titres performed with PfCLAG peptides A, B and C and those with those using PfMSP $1_{19}$ and PvMSP1- ${ }_{19}$ antigens. The selected samples corresponded to sera from patients with positive PCR for P. vivax and negative PCR for P. falciparum and with antibody reactivity with at least one of the PfCLAG9 peptides. Only 9 (15.2\%) out of 59 sera from asymptomatic patients reacted against the heterologous $\mathrm{PfMSP}_{19}$, indicating that the large majority of these patients had not been recently exposed to $P$. falciparum infections. Among patients with clinical symptoms, only 16 (28.6\%) out of 59 sera from $P$. vivax patients presented reactivity against PfMSP1- ${ }_{10}$ antigen while $100 \%$ reacted against the homologous PvMSP1- ${ }_{19}$.

Molecular basis of the cross reactivity - In order to understand the molecular basis for the observed CLAG9 cross reactivity we investigated possible sequence iden-

TABLE

Enzyme-linked-immunosorbent-assay test comparing sera reactivity of Plasmodium falciparum and Plasmodium vivax clinical patients and asymptomatic (Asymp) parasite carriers against PfCLAG9 peptides A, B and C

Non parametric

Mann-Whitney

test P. falciparum P. vivax

\begin{tabular}{|c|c|c|c|c|c|c|c|c|c|c|c|}
\hline \multirow{2}{*}{$\begin{array}{l}\text { Peptides } \\
\text { PfCLAG9 }\end{array}$} & \multirow[b]{2}{*}{ Group } & \multirow[b]{2}{*}{$\mathrm{n}$} & \multirow[b]{2}{*}{ Mean } & \multicolumn{2}{|c|}{$95 \% \mathrm{CI}$} & \multirow[b]{2}{*}{$\mathrm{p}$} & \multirow[b]{2}{*}{$\mathrm{n}$} & \multirow[b]{2}{*}{ Mean } & \multicolumn{2}{|c|}{$95 \% \mathrm{CI}$} & \multirow[b]{2}{*}{$\mathrm{p}$} \\
\hline & & & & Lower & Upper & & & & Lower & Upper & \\
\hline \multirow[t]{3}{*}{ A } & Symp & 42 & 5.494 & 4.630 & 6.357 & 0.0004 & 33 & 1.978 & 1.527 & 2.430 & 0.0001 \\
\hline & Asymp & 64 & 3.747 & 3.101 & 4.392 & & 52 & 3.872 & 3.368 & 4.375 & \\
\hline & Total & 106 & 4.439 & 3.903 & 4.975 & & 85 & 3.137 & 2.735 & 3.538 & \\
\hline \multirow[t]{3}{*}{ B } & Symp & 41 & 6.055 & 4.982 & 7.128 & 0.0094 & 46 & 1.963 & 1.672 & 2.255 & 0.0001 \\
\hline & Asymp & 68 & 7.940 & 7.052 & 8.829 & & 56 & 5.745 & 4.647 & 6.842 & \\
\hline & Total & 109 & 7.231 & 6.534 & 7.928 & & 102 & 4.039 & 3.327 & 4.752 & \\
\hline \multirow[t]{3}{*}{$\mathrm{C}$} & Symp & 44 & 2.667 & 2.165 & 3.169 & 0.0141 & 32 & 1.384 & 1.154 & 1.614 & 0.0001 \\
\hline & Asymp & 66 & 3.718 & 3.113 & 4.324 & & 57 & 2.687 & 2.276 & 3.099 & \\
\hline & Total & 110 & 3.298 & 2.877 & 3.729 & & 89 & 2.219 & 1.916 & 2.522 & \\
\hline \multirow[t]{3}{*}{$\mathrm{PfMSP}{ }_{19}$} & Symp & - & - & - & - & - & 16 & 2.598 & 1.819 & 3.376 & 0.0579 \\
\hline & Asymp & - & - & - & - & - & 9 & 3.604 & 2.957 & 4.252 & \\
\hline & Total & - & - & - & - & - & 25 & 2.96 & 2.404 & 3.516 & \\
\hline \multirow{3}{*}{$\mathrm{PvMSP}_{1-19}$} & Symp & 17 & 2.287 & 1.586 & 2.988 & 0.1361 & 56 & 3.068 & 2.591 & 3.545 & 0.2513 \\
\hline & Asymp & 29 & 2.767 & 2.271 & 3.262 & & 59 & 2.556 & 2.231 & 2.880 & \\
\hline & Total & 46 & 2.589 & 2.194 & 2.985 & & 115 & 2.805 & 2.520 & 3.090 & \\
\hline
\end{tabular}

the $\mathrm{p}$ values shown are from the non-parametric Mann-Whitney $U$ test. Only positive (reactivity index $\geq 1$ ) results were considered for descriptive and tests statistics. CI: confidence interval; MSP1- ${ }_{19}$ : merozoite surface protein of $P$. falciparum; PvMSP1- ${ }_{19}$ : MSP of P. vivax; Symp: symptomatic. 
tities and similarities between PfCLAG9 synthetic peptides A, B and C and the P. vivax CLAG orthologs encoded on chromosomes 7, PvCLAG7 (Moreno-Perez et al. 2011) and 8, PvCLAG8 (Carlton et al. 2008). The other hypothetical genes deposited, such as PvCLAG14, showed no significant similarities for comparison.

As shown in Fig. 3A, significant similarity $(84.44 \%)$ and identity $(64.4 \%)$ was observed between peptide B (PfCLAG9 - residues 901-944) with amino acids residues 888-932 of PvCLAG7. Peptide B presents also significant similarity $(86.66 \%)$ and identity $(55.6 \%)$ with $P$. vivax CLAG 8 , but the similarity amino acids are found at a slightly shifted position (897-941) of PvCLAG8 (Fig. 3B). In addition, a lower but still significant degree of similarity was observed for peptides A and peptide C (Fig. 3A, B).

The highest identity/similarity observed with peptide B (residues 901-944 of PfCLAG9 and residue 888-932 of PvCLAG7) coincided with the highest ELISA RI values, or 7.9 and 6.0 for P. falciparum asymptomatic and symptomatic infections, respectively and 5.7 and 1.9 for $P$. vivax. Similar pattern was shown for peptide A (Table).
These results show that cross reactivity is likely due to similarity between the CLAG proteins of both parasite species, supporting the notion that PvCLAG7 and PvCLAG8 are orthologs of PfCLAG9.

Cross reactive antibodies recognise epitopes in RBCs infected by $P$. falciparum or P. vivax. Fig. 4 represents the result of indirect immunofluorescence assays of trophozoite and schizonts stages of $P$. vivax and $P$. falciparum using mouse antibodies to synthetic peptide B of PfCLAG9 antigen. As shown, the pattern of parasites labelling in the PRBCs is very similar. Comparable profiles were observed in schizonts incubated with antisera to PfCLAG A, PfCLAG B and PfCLAG C (data not shown). No positive labelling was observed in ring stages.

\section{DISCUSSION}

Results in the present study show that antibodies with high reactivity to PfCLAG9 are found in asymptomatic P. falciparum parasite carriers patients correlating with clinical immunity and supporting previous epidemiological observations in Papua New Guinea (Trenholme et al. 2005). Interestingly, high reactive
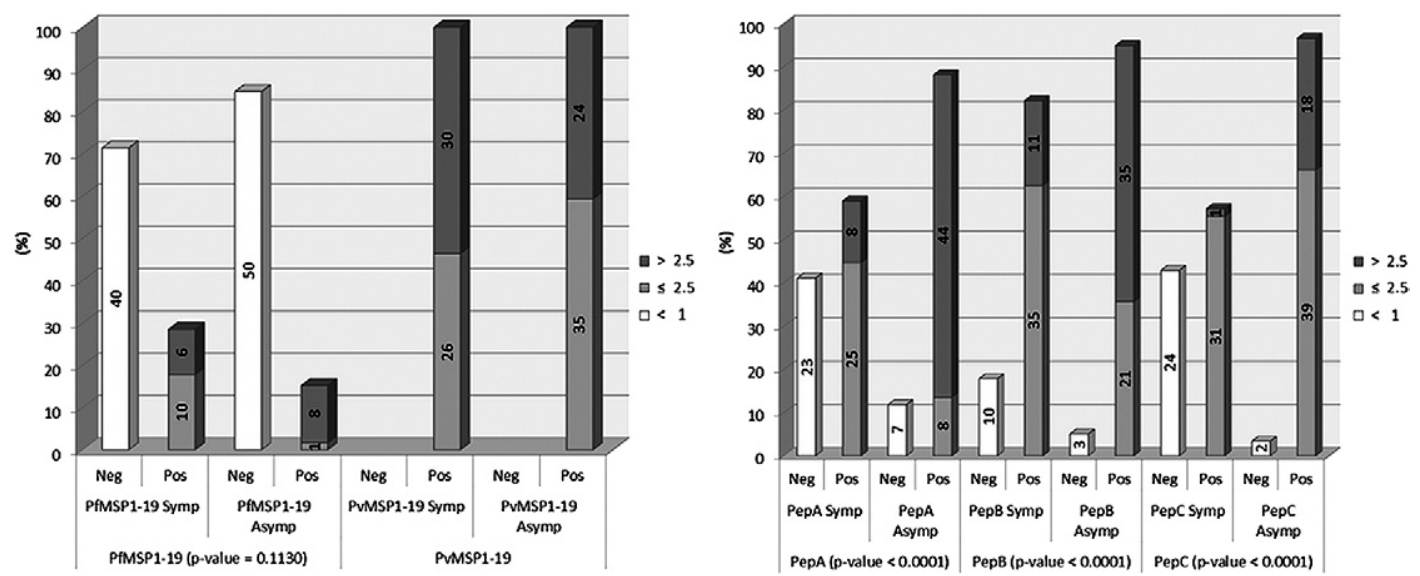

Fig. 2: comparison of frequency and antibody serum samples levels of each recombinant protein merozoite surface protein (MSP) $1-_{19}$ of Plasmodium. falciparum and Plasmodium vivax antigens carries positive PfCLAG9 with P. vivax asymptomatic (Asymp) and symptomatic (Symp). Negative $(\mathrm{Neg})[$ reactivity index $(\mathrm{RI})<1]$ and positive $(\mathrm{Pos})(\mathrm{RI} \geq 1)$ sera counts where done using Fisher's exact test.

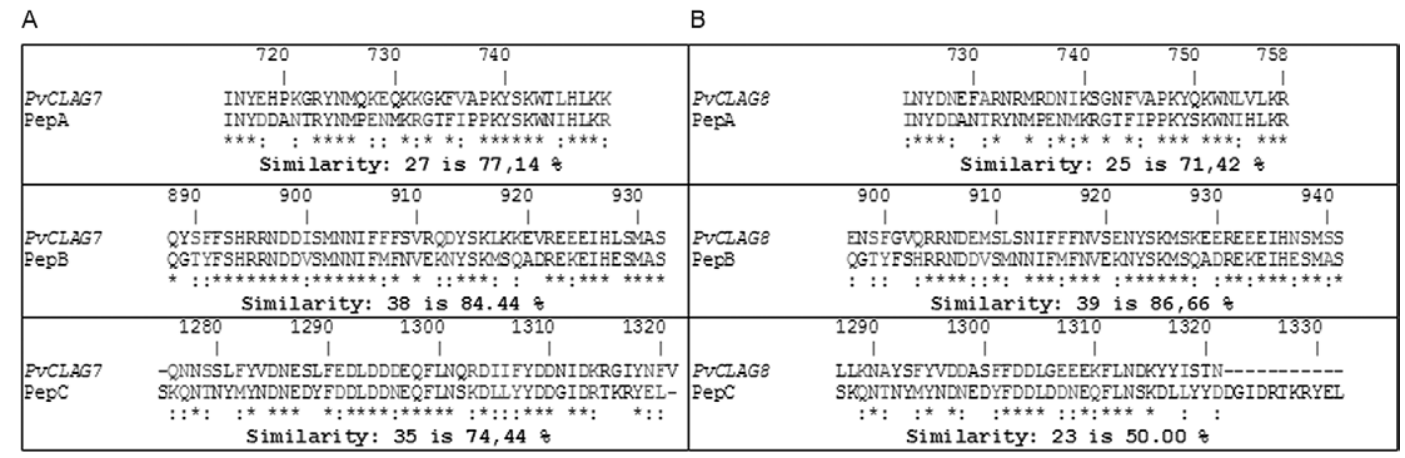

Fig. 3: sequence similarity between synthetic PfCLAG9 peptides A, B and C with the corresponding regions of PvCLAG7 encoded on chromosome 7 (A) and CLAG8 encoded on chromosome 8 (B). 

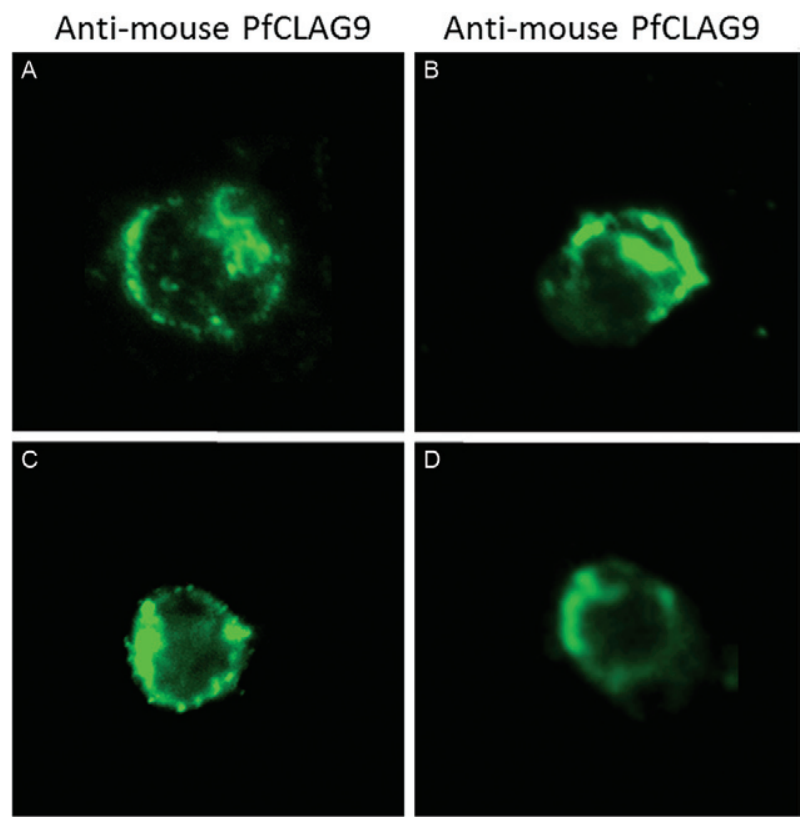

Fig. 4: indirect immunofluorescence pattern of mouse polyclonal antiserum against synthetic peptides of PfCLAG9 in parasitised red blood cells (PRBC) with schizonts of Plasmodium vivax (A) and Plasmodium falciparum (B) and in PRBC with trophozoites of $P$. vivax $(\mathrm{C})$ and $P$. falciparum (D), respectively, by goat anti-mouse IgG Alexa Fluor 488.

cross-reactive antibodies against PfCLAG9 peptides were also found in sera of asymptomatic $P$. vivax malaria parasite carriers patients and this is the main focus of the discussion.

The first point to considerer is if the observed cross reactivity of antibodies corresponds to some immunephysiological process, it could be related to interactions between malaria parasites in the vertebrate host. Previous studies with semi-immune children in Papua Guinea, harbouring mixed infections by both Plasmodium species, have shown that parasite density of Plasmodium species in mixed infections oscillates around a threshold and that peaks of infection with each species do not coincide (Bruce et al. 2000, Bruce \& Day 2003). The authors proposed that malaria parasitaemia is controlled in a density-dependent manner in these semi-immune children by a cross-species parasite regulatory mechanism involving variant parasite antigens.

Existence of regulatory interactions between parasites in mixed infections has been previously also suggested by Bouharoun-Tayoun et al. (1990). In their experiments, passive transfer of IgG collected from adult immune donors to $P$. falciparum malaria infections, from West Africa, to young Thai patient receivers, with active $P$. falciparum infections, resulted in a significant decrease of the $P$. falciparum parasitaemia and improvement of clinical symptoms. However, in three of the receivers, following administration of the anti-falciparum immune $\operatorname{IgG}$, the development of a new malaria infection by $P$. vivax was observed with an increasing parasitaemia that needed chloroquine treatment.
Malaria surveillance performed by our group in RO resulted in similar effects. After treating all identified symptomatic and asymptomatic $P$. falciparum parasite carriers in the riverside locality of Vila Candelária, no more clinical cases of falciparum malaria were observed in the following year. However, the number of clinical $P$. vivax cases doubled in this locality, from 53 in the previous year to 105 in the following year (Tada 2008, Tada et al. 2012). Both observations might be explained if clearing of the $P$. falciparum parasites results in the elimination of an "inhibitory signal", affecting the multiplication of $P$. vivax parasite cells, either of hypnozoite origin or from a quiescent infection.

These and other observations (Boyd \& Kitchen 1938, Maitland et al. 1997) indicate that interactions between parasites affecting population densities in mixed infections do exist, but no convincing mechanisms have been found to explain the nature of the interaction process. It can be speculated that a negative inhibitory factor produced by a dominant species would have an advantageous effect to avoid competition for nutrients obtained from the host and to avoid compromising deleterious effects, which would indirectly compromise the dominant parasite survival. Such a hypothetical inhibitor could be of immunological origin. The authors of studies with semi-immune children in Papua Guinea proposed that parasitaemia are controlled in a density-dependent manner by variant antigens from one of the partners (Bruce \& Day 2003). Our results suggest a possible role for PfCLAG9 antigen in which anti-PfCLAG9 antibodies originated during $P$. falciparum infection would recognised a vivax parasite target, possibly the PvCLAG7 ortholog. The following elements in favour of this hypothesis may be presented: (i) PfCLAG9 product seems to participate in metabolic remodelling of PRBC like it was demonstrated for PfCLAG3 (Goel et al. 2010, Nacer et al. 2011, Nguitragool et al. 2011) and suggested for PfClag9, (ii) PvCLAG7 by its similarities with PfCLAG9 seems to represent orthologs molecules (Moreno-Perez et al. 2011) and CLAG8 and (iii) search of similarities between members of the clag families of $P$. falciparum and $P$. vivax indicate that similarities between protein is good candidate for being assessed in cellular, immunological and functional studies aimed at establishing its role during invasion (Cowman et al. 2012)

While the clinical immunity status in vivax malaria correlates with repetitive infections (Alves et al. 2002, Gil et al. 2007) we hypothesise that the higher RI antiPfCLAG9 values observed among asymptomatic $P$. vivax patients (Fig. 2, Table) are originate from a boosting effect by the ortholog PvCLAG7 and eight homologous sequences or, eventually, in mixed infections, directly by PfCLAG9. Immunoclinical follow up of selected mixed infected patients and immuno-parasitological studies are being undertaken in our laboratory to test this hypothesis.

\section{ACKNOWLEDGEMENTS}

To Dr Victor Nussenzweig and Dr Luiz Shozo Ozaki, for reviewing the paper, and to all the technical staff of CEPEM, from the Health Department of RO, for patient's examination and care. 


\section{REFERENCES}

Alves FP, Durlacher RR, Menezes MJ, Krieger H, da Silva LHP, Camargo EP 2002. High prevalence of asymptomatic Plasmodium vivax and Plasmodium falciparum infections in native Amazonian populations. Am J Trop Med Hyg 66: 641-648.

Andrysiak PM, Collins WE, Campbell GH 1986. Concentration of Plasmodium ovale and Plasmodium vivax-infected erythrocytes from non humam primate blood using Percoll gradients. Am J Trop Med Hyg 35: 251-254.

Bouharoun-Tayoun H, Attanath P, Sabchareon A, Chongsuphajaisiddhi T, Druilhe P 1990. Antibodies that protect humans against Plasmodium falciparum blood stages do not on their own inhibit parasite growth and invasion in vitro, but act in cooperation with monocytes. J Exp Med 172: 1633-1641.

Boyd MF, Kitchen SF 1938. Vernal vivax activity in persons simultaneously innoculated with Plasmodium vivax and Plasmodium falciparum. Am J Trop Med Hyg 18: 505-514.

Braga EM, Barros RM, Reis TA, Fontes CJ, Morais CG, Martins MS, Krettli AU 2002. Association of the IgG response to Plasmodium falciparum merozoite protein (C-terminal 19KD) with clinical immunity to malaria in the Brazilian Amazon Region. Am J Trop Med Hyg 66: 461-466.

Bruce MC, Day KP 2003. Cross species regulation of Plasmodium parasitemia in semi-immune children from Papua New Guinea. Trends Parasitol 19: 271-277.

Bruce MC, Donnelly CA, Alperts MP, Galinsk MR, Barwell JW, Waliker D, Day KP 2000. Cross-species interaction in malaria parasites in humans. Science 287: 845-848.

Cao OJ, Kaneko O, Thongkukiatkul A, Tachibana M, Otsuki H, Gao Q, Tsuboi T, Torii M 2009. Rhoptry neck protein RON2 forms a complex with microneme protein, AMA1 in Plasmodium falciparum merozoite. Parasitol Int 58: 29-35.

Carlton JM, Adams JH, Silva JC, Bidwell SL, Lorenzi H, Caler E, Crabtree J, Angiuoli SV, Merino EF, Amedeo P 2008. Comparative genomics of the neglected human malaria parasite Plasmodium vivax. Nature 455: 757-763.

Cowman AF, Berry D, Baum J 2012. The cell biology of disease: The cellular and molecular basis for malaria parasite invasion of the human red blood cell. J Cell Biol 198: 961-971.

de Koning-Ward TF, Gilson PR, Boddey JA, Rug M, Smith BJ, Papenfuss AT, Sanders PR, Lundie RJ, Maier AG, Cowman AF, Crabb BS 2009. A novel protein export machine in malaria parasites. Nature 459: 945-949.

Emini EA, Hughes JV, Perlow DS, Boger J 1985. Induction of hepatitis A virus-neutralizing antibody by a virus-specific synthetic peptide. J Virol 55: 836-839.

Gardiner DL, Holt DC, Thomas EA, Kemp DJ, Trenholme KR 2000. Inhibition of Plasmodium falciparum clag9 gene function by antisense RNA. Mol Biochem Parasitol 110: 33-41.

Gardiner DL, Spielmann T, Dixon MW, Hawthorne PL, Ortega MR, Anderson KL, Skinner-Adams TS, Kemp DJ, Trenholme KR 2004. CLAG 9 is located in the rhoptries of Plasmodium falciparum. Parasitol Res 93: 64-67.

Gardner MJ, Neil H, Eula F, Owen W, Matthew B, Richard WH, Jane MC, Arnab P, Karen EN, Sharen B, Ian TP, Keith J, Jonathan AE, Kim R, Steven LS, Alister C 2002. Genome sequence of the human malaria parasite Plasmodium falciparum. Nature 419: 498-511.

Gil LH, Alves FP, Zieler H, Salcedo JM, Durlacher RR, Cunha RP, Tada MS, Camargo LM, Camargo EP, da Silva LHP 2003. Seasanol malaria transmission and variation of anopheline density in two distinct endemic areas in Brazilian Amazonia. J Med Entomol 40: 636-641.

Gil LHS, Tada MS, Katsuragawa TH, Ribolla PEM, da Silva LHP 2007. Urban and suburban malaria in Rondônia (Brazilian Western Amazon). II. Perennial transmissions with high anopheline densities are associated with human environmental changes. Mem Inst Oswaldo Cruz 102: 271-276.

Goel S, Valiyaveettil M, Achur RN, Goyal A, Mattei D, Salanti A, Trenholme KR, Gardiner DL, Gowda DC 2010. Dual stage synthesis and crucial role of cytoadherence-linked asexual gene 9 in the surface expression of malaria parasite VAR proteins. Proc Natl Acad Sci USA 107: 16643-16648.

Holt DC, Bourke PF, Mayo M, Kemp DJ 1998. A high resolution map of chromosome 9 of Plasmodium falciparum. Mol Biochem Parasitol 97: 229-233.

Holt DC, Fischer K, Tchavtchitch M, Wilson DW, Hauquitz NE, Hawthorne PL, Gardiner DL, Trenholme KR, Kemp DJ 2001. Clags in Plasmodium falciparum and other species of Plasmodium. Mol Biochem Parasitol 118: 259-263.

Iriko H, Kaneko O, Otsuki H, Tsuboi T, Su XZ, Tanabe K, Torii M 2008. Diversity and evolution of the rhoph1/clag multigene family of Plasmodium falciparum. Mol Biochem Parasitol 158: 11-21.

Kaneko O 2007. Erythrocyte invasion: vocabulary and grammar of the Plasmodium rhoptry. Parasitol Int 56: 255-262.

Kaneko O, Bryan YS, Lim Y, Iriko H, Ling IT, Otsuki H, Grainger M, Tsuboi T, Adams JH, Mattei D, Holder AA, Torii M 2005. Apical expression of three RhopH1/CLAG proteins as components of the Plasmodium falciparum RhopH complex. Mol Biochem Parasitol 143: 20-28.

Kaneko O, Tsuboi T, Ling IT, Howell S, Shirano M, Tachibana M, Cao YM, Holder AA, Torii M 2001. The high molecular mass rhoptry protein, RhopH1, is encoded by members of the clag multigene family in Plasmodium falciparum and Plasmodium yoelii. Mol Biochem Parasitol 118: 223-231.

Karplus PA, Schulz GE 1985. Prediction of chain flexibility in proteins - a tool for the selection of peptide antigens. Naturwissenschafren 72: 212-213.

Katsuragawa TH, Cunha RP, de Souza DC, Gil LH, Cruz RB, Silva Ade A, Tada MS, Pereira-da-Silva LH 2009. Malaria and hematological aspects among residents to be impacted by reservoirs for the Santo Antônio and Jirau Hydroelectric Power Stations, Rondônia state, Brazil. Cad Saude Publica 25: 1486-1492.

Katsuragawa TH, Gil LH, Tada MS, de Almeida e Silva A, Costa JD, Araújo M da S, Escobar AL, Pereira-da-Silva LH 2010. The dynamics of transmission and spatial distribution of malaria in riverside areas of Porto Velho, Rondônia, in the Amazon Region of Brazil. PLoS ONE 5: e9245.

Kolaskar AS, Tongaonkar PC 1990. A semi-empirical method for prediction of antigenic determinants on protein antigens. FEBS Lett 276: $172-174$

Lambros C, Vanderberg JP 1979. Synchronization of Plasmodium falciparum erythrocytic stages in culture. J Parasitol 65: 418-420.

Larsen JE, Lund O, Nielsen M 2006. Improved method for predicting linear B-cell epitopes. Immunome Res 2: 2.

Lelievre J, Berry A, Benoit-Vical F 2005. An alternative method for Plasmodium culture synchronization. Exp Parasitol 109: 195-197.

Ling IT, Florens L, Dluzewski AR, Kaneko O, Grainger M, Yim Lim BY, Tsuboi T, Hopkins JM, Johnson JR, Torii M, Bannister LH, Yates JR 3rd, Holder AA, Mattei D 2004. The Plasmodium falciparum CLAG9 gene encodes a rhoptry protein that is transferred to the host erythrocyte upon invasion. Mol Microbiol 52: 107-118. 
Maitland K, Williams TM, Newbold CI 1997. Plasmodium vivax and Plasmodium. falciparum: biological interactions and the possibility of cross-species immunity. Parasitol Today 13: 227-231.

Mayer AG, Cooke BM, Cowman AF, Tilley L 2009. Malaria parasite proteins that remodel the host erythrocyte. Nat Rev Microbiol 7: 341-354.

Moreno-Perez DA, Mongui A, Soler LN, Sanchez-Ladino M, Patarroyo MA 2011. Identifying and characterizing a member of the RhopH1/CLAG family in Plasmodium vivax. Gene 481: 17-23.

Nacer A, Roux E, Pomel Scheldig-Benatar, Sakamto H, Scherf A, Mattei D 2011. clag9 is not essential for PfEMP1 surface expression in non-cytoadherent Plasmodium falciparum parasites with a chromosome 9 deletion. PLoS ONE 6: e29039.

Nguitragool W, Bokhari AAB, Pillai AD, Rayavara K, Sharma P, Turpin Baravind L, Desai SA 2011. Malaria parasite clag3 genes determine channel mediated nutrient uptake by infected red blood cells. Cell 145: 665-677.

Parker JM, Guo D, Hodges RS 1986. New hydrophilicity scale derived from high-performance liquid chromatography peptide retention data: correlation of predicted surface residues with antigenicity and X-ray-derived accessible sites. Biochemistry 25: 5425-5432.

Richard D, Mac Raild CA, Riglar DT, Cham JA, Foley M, Baum J, Ralph SA, Norton RS, Cowman AF 2010. Interaction between Plasmodium falciparum apical membrane antigen 1 and the rhoptry neck protein complex defines a key step in the erythrocyte invasion process of malaria parasites. J Biol Chem 285: 14815-14822.

Shirley MW, Biggs BA, Forsyth KP, Brown HJ, Thompson JKGV, Kemp DJ 1990. Chromosome 9 from independent clones and isolates of Plasmodium falciparum undergoes subtelomeric deletions with similar breakpoints in vitro. Mol Biochem Parasitol 40: $137-145$

Snounou G 1996. Detection and identification of the four malaria parasite species Infecting humans by PCR amplification. Meth Mol Biol 50: 263-291.
Tada MS 2008. Epidemiologia da malária em área urbana e suburbana de Porto Velho. Ensaios preliminares de inovação em métodos de controle, PhD Thesis, Programa de Pós-Graduação em Biologia Experimental, Universidade Federal de Rondônia, Porto Velho, $111 \mathrm{pp}$.

Tada MS, Ferreira RGM, Katsuragawa TH, Martha RCD, Costa JDN, Albrecht L, Wunderlich G, da Silva LHP 2012. Asymptomatic infections by Plasmodium falciparum and Plasmodium vivax in the Brazilian Amazon Basin: to treat or not to treat? Mem Inst Oswaldo Cruz 107: 621-629.

Tada MS, Marques RP, Mesquita E, Martha RCD, Rodrigues JA, Costa JDN, Pepelascov RR, Katsuragawa TH, Pereira-da-Silva LH 2007. Urban malaria in the Brazilian western Amazon Region. I. High prevalence of asymptomatic carriers in an urban riverside district is associated with a high level of clinical malaria. Mem Inst Oswaldo Cruz 102: 263-269.

Thompson JD, Higgins DG, Gibson TJ 1994. CLUSTALW: improving the sensitivity of progressive multiple sequence alignment through sequence weighting, position-specific gap penalties and weight matrix choice. Nucleic Acids Res 22: 4673-4680.

Trager W, Jensen JB 1976. Human malaria parasites in continuous culture. Science 193: 673-675.

Trenholme KR, Boutlis VS, Kuns R, LaGog M, Bockarie M, Gatton ML, Kemp DJ, Good MF, Anstey NM, Gardiner DL 2005. Antibody reactivity to linear epitopes of Plasmodium falciparum cytoadherence-linked asexual gene 9 in asymptomatic children and adults from Papua New Guinea. Am J Trop Med Hyg 2: 708-713.

Trenholme KR, Gardiner DL, Holt DC, Thomas EA, Cowman AF, Kemp DJ 2000. clag9: a cytoadherence gene in Plasmodium falciparum essential for binding of parasitized erythrocytes to CD36. Proc Natl Acad Sci USA 97: 4029-4033.

Walliker D, Quakyi IA, Wellems TE, McCutchan TF, Szarfman A, London WT, Corcoran LM, Burkot TR, Carter R 1987. Genetic analysis of the human malaria parasite Plasmodium falciparum. Science 236: 1661-1666. 